\title{
Complete blood cell count components and coronary slow-flow phenomenon
}

This article was published in the following Dove Press journal:

Therapeutics and Clinical Risk Management

2 December 2016

Number of times this article has been viewed

\author{
Nasim Arjmand \\ Mohammad Reza Dehghani \\ Department of Cardiology, \\ Seyyed-al-Shohada Heart Center, \\ Urmia University of Medical Sciences, \\ Urmia, Iran
}

\section{Dear editor}

Despite the implementation of preventive strategies, ischemic heart disease and stroke remain the main causes of mortality and morbidity worldwide. ${ }^{1,2}$ Of the cardiovascular diseases, coronary slow-flow phenomenon (CSFP), with a prevalence rate of $1 \%-7 \%$ among patients undergoing diagnostic coronary angiography, has been found to be associated with cardiovascular events, including cardiac arrhythmia and acute coronary syndrome.${ }^{3-5}$ However, the potential mechanisms involved in the pathogenesis of CSFP remain unknown. Microvascular and endothelial dysfunctions, inflammation, diffuse atherosclerosis, and increased platelet aggregability have been reported to be the main possible etiologies for CSFP.., 7

We read the article by Altas et $\mathrm{al}^{8}$ regarding the relationship between the eosinophil count and the CSFP with great interest. They showed that of the complete blood count components (white blood cells, neutrophils, eosinophils, hemoglobin, and platelets), eosinophils were associated with the CSFP. In this study, eosinophil count was found to be elevated in patients with the CSFP compared with those with normal coronary arteries. In addition, higher eosinophil count was directly correlated with thrombolysis in myocardial infarction frame count in the CSFP group.

When interpreting this study, we should consider some points which are of great importance.

Biomarkers are used as diagnostic tools for risk stratification of cardiovascular diseases, of which complete blood cell count components have been shown to be a good and easily available predictor of cardiovascular events, particularly among patients with coronary artery disease. ${ }^{9}$ In addition to ischemic heart diseases, complete blood cell count components have also been found to be associated with the presence of CSFP; however, study results have been inconsistent in the literature. Several reports have demonstrated that the mean platelet volume is higher in patients with CSFP compared to individuals with normal coronary arteries; ${ }^{10-12}$ however, in one study the elevated mean platelet volume has not been associated with CSFP. ${ }^{13}$ Other platelet volume indices, including platelet distribution width and platelet-large cell ratio, have been associated with the presence of CSFP. ${ }^{6}$ On the other hand, the relationship between leukocyte subtypes and the CSFP has been inconsistent in previous studies. In most of the studies, total white blood cell count has not been the predictor of CSFP..$^{6,13-15}$ In contrast, Akboga et $\mathrm{al}^{16}$ found that a higher white blood cell count is associated with CSFP. Regarding the red blood cell subtypes, results have also been diverse among studies. Two studies demonstrated that red cell distribution width correlated with the presence of CSFP, ${ }^{15,17}$ while in one study it did not. ${ }^{6}$ Furthermore, the elevated levels of
Correspondence: Nasim Arjmand Department of Cardiology, Seyyed-al-Shohada Heart Center, Urmia University of Medical Sciences, I7 Shahrivar Blvd, Urmia 57/874944I, Iran Email nasim.arjmand@gmail.com 
hemoglobin ${ }^{11}$ and hematocrit ${ }^{15}$ have been associated with the CSFP. In addition to these regular complete blood cell count components, some novel biomarkers have also been found to be associated with the CSFP, including elevated neutrophilto-lymphocyte ratio, ${ }^{14}$ increased platelet-to-lymphocyte ratio, ${ }^{16}$ and decreased lymphocyte-to-monocyte ratio. ${ }^{18}$ All these novel biomarkers are inflammation-based and have been useful in diagnosing other inflammatory diseases. White blood cell to mean platelet volume ratio is another novel biomarker examined in coronary artery disease and metabolic syndrome, ${ }^{19,20}$ which may be useful to detect the presence of CSFP as well.

Given the findings of previous studies, it is likely that the two main pathophysiologic mechanisms involved in the development of CSFP may include the enhancement of inflammation status and thrombogenesis. However, due to inconsistent results with regard to the biomarkers, further studies are required to elucidate the pathogenesis of this phenomenon. In addition, the inconsistent findings regarding the complete blood cell count may be explained by the notion that the prevalence of CSFP is low and the majority of studies included small sample sizes. Further large-scale studies, including all these parameters in the final analysis, can clarify this inconsistency.

\section{Acknowledgment}

We thank Dr Yousef Rezaei for his great contribution in the editing of this letter.

\section{Disclosure}

The authors report no conflicts of interest in this communication.

\section{References}

1. Murray CJ, Lopez AD. Measuring the global burden of disease. N Engl J Med. 2013;369(5):448-457.

2. Amiri-Nikpour MR, Nazarbaghi S, Ahmadi-Salmasi B, Mokari T, Tahamtan U, Rezaei Y. Cerebrolysin effects on neurological outcomes and cerebral blood flow in acute ischemic stroke. Neuropsychiatr Dis Treat. 2014;10:2299-2306.

3. Amasyali B, Turhan H, Kose S, et al. Aborted sudden cardiac death in a 20-year-old man with slow coronary flow. Int J Cardiol. 2006;109(3): $427-429$.
4. Cannon RO. Microvascular angina and the continuing dilemma of chest pain with normal coronary angiograms. J Am Coll Cardiol. 2009; 54(10):877-885.

5. Wozakowska-Kaplon B, Niedziela J, Krzyzak P, Stec S. Clinical manifestations of slow coronary flow from acute coronary syndrome to serious arrhythmias. Cardiol J. 2009;16(5):462-468.

6. Seyyed-Mohammadzad MH, Khademvatani K, Kerachian A, Eskandari R, Rezaei Y. Slow coronary flow phenomenon and increased platelet volume indices. Korean Circ J. 2014;44(6):400-405.

7. Turhan H, Saydam GS, Erbay AR, et al. Increased plasma soluble adhesion molecules; ICAM-1, VCAM-1, and E-selectin levels in patients with slow coronary flow. Int J Cardiol. 2006;108(2):224-230.

8. Altas Y, Kurtoglu E, Yaylak B, et al. The relationship between eosinophilia and slow coronary flow. Ther Clin Risk Manag. 2015;11: $1187-1191$

9. Dehghani MR, Rezaei Y, Taghipour-Sani L. Superiority of total white blood cell count over other leukocyte differentials for predicting long-term outcomes in patients with non-ST elevation acute coronary syndrome. Biomarkers. 2014;19:378-384.

10. Nurkalem Z, Alper AT, Orhan AL, et al. Mean platelet volume in patients with slow coronary flow and its relationship with clinical presentation. Turk Kardiyol Dern Ars. 2008;36(6):363-367.

11. Isik T, Ayhan E, Uyarel $\mathrm{H}$, et al. Increased mean platelet volume associated with extent of slow coronary flow. Cardiol J. 2012;19(4): 355-362.

12. Celik T, Yuksel UC, Bugan B, et al. Increased platelet activation in patients with slow coronary flow. J Thromb Thrombolysis. 2010;29(3): 310-315.

13. Kaya Z, Günebakmaz Ö, Yıldız A, et al. Mean platelet volume is not associated with coronary slow flow: a retrospective cohort study. Anatol J Cardiol. 2015;15(1):18-24.

14. Doğan M, Akyel A, Çimen T, et al. Relationship between neutrophil to lymphocyte ratio and slow coronary flow. Clin Appl Thromb Hemost. 2015;21(3):251-254.

15. Ghaffari S, Tajlil A, Aslanabadi N, et al. Clinical and laboratory predictors of coronary slow flow in coronary angiography. Perfusion. Epub $2016 \mathrm{Jul} 13$

16. Akboga MK, Canpolat U, Balci KG, et al. Increased platelet to lymphocyte ratio is related to slow coronary flow. Angiology. 2016;67(1): $21-26$.

17. Kalay N, Aytekin M, Kaya MG, et al. The relationship between inflammation and slow coronary flow: increased red cell distribution width and serum uric acid levels. Turk Kardiyol Dern Ars. 2011;39(6): 463-468.

18. Yayla Ç, Akboğa MK, Gayretli Yayla K, et al. A novel marker of inflammation in patients with slow coronary flow: lymphocyte-to-monocyte ratio. Biomark Med. 2016;10(5):485-493.

19. Dehghani MR, Rezaei Y, Fakour S, Arjmand N. White blood cell count to mean platelet volume ratio is a prognostic factor in patients with non-ST elevation acute coronary syndrome with or without metabolic syndrome. Korean Circ J. 2016;46(2):229-238.

20. Dehghani MR, Rezaei Y, Taghipour-Sani L. White blood cell count to mean platelet volume ratio as a novel non-invasive marker predicting long-term outcomes in patients with non-ST elevation acute coronary syndrome. Cardiol J. 2015;22(4):437-445. 
Dove Medical Press encourages responsible, free and frank academic debate. The content of the Therapeutics and Clinical Risk Management 'letters to the editor' section does not necessarily represent the views of Dove Medical Press, its officers, agents, employees, related entities or the Therapeutics and Clinical Risk Management editors. While all reasonable steps have been taken to confirm the content of each letter, Dove Medical Press accepts no liability in respect of the content of any letter, nor is it responsible for the content and accuracy of any letter to the editor.

Therapeutics and Clinical Risk Management

Dovepress

\section{Publish your work in this journal}

Therapeutics and Clinical Risk Management is an international, peerreviewed journal of clinical therapeutics and risk management, focusing on concise rapid reporting of clinical studies in all therapeutic areas, outcomes, safety, and programs for the effective, safe, and sustained use of medicines. This journal is indexed on PubMed Central, CAS,
EMBase, Scopus and the Elsevier Bibliographic databases. The manuscript management system is completely online and includes a very quick and fair peer-review system, which is all easy to use. Visit http://www.dovepress.com/testimonials.php to read real quotes from published authors.

Submit your manuscript here: http://www.dovepress.com/therapeutics-and-clinical-risk-management-journal 